\title{
КЛІНІЧНА МЕДИЦИНА
}

(C) Manusha Yu.I., Kazakov Yu.M., Trybrat T.A., Ischeykin K.E.

UDC 6160 - 020-031.81.11./ - 036.18 - 06: [616.127 - 003.4+616.36-003.826]

DOI https://doi.org/10.31718/mep.2019.23.3-4.01

\section{PECULIARITIES OF SYSTEMIC INFLAMMATION OF LOW INTENSITY IN PATIENTS WITH STABLE CORONARY HEART DISEASE CONCURRENT WITH NON-ALCOHOLIC FATTY LIVER DISEASE}

Manusha Yu.I., Kazakov Yu.M., Trybrat T.A., Ischeykin K.E.

Ukrainian Medical Stomatological Academy, Poltava

\begin{abstract}
Ішемічна хвороба серця та неалкогольна жирова хвороба печінки $є$ актуальними проблемами сьогодення в Україні та світі. Функціональні розлади роботи печінки потенціюють розвиток та прогресування ішемічної хвороби серця. Пусковим процесом атеросклерозу (AC) є хронічне системне запалення низької інтенсивності. Цей погляд почав активно формуватися останні два десятиріччя. Метою роботи було вивчення особливості системного запалення низької інтенсивності у хворих на стабільну ішемічну хворобу серця у поєднанні з неалкогольною жировою хворобою печінки. До дослідження були залучені 135 осіб хворих на IXС: стенокардію напруги стабільну, I-II ФК, СН 0-I у поєднанні з неалкогольною жировою хворобою печінки та 30 здорових осіб. 3 метою дослідження рівня активності хронічного системного запалення низької інтенсивності у хворих визначали у крові рівень цитокінів -TNFa та IL-10, вміст реактанту гострої фази та фактору коагуляції - ФГ, маркер ендотеліальної дисфункції - кількість циркулюючих ендотеліальних мікрочасточок (ЦЕM) CD32+CD40+ та рівень експресії гену IkBa NF-kB у мононуклеарах периферичної крові. Дослідження рівню експресії гену mRNA IkBa у мононуклеарах крові, що відображає рівень транскрипційної активності NF-kB, у хворих на стабільну IXC та IХC у поєднанні з НАЖХП показало достовірне підвищення показника експресія гену mRNA IkBa на 88,5\% порівняно з хворими лише на стабільну IXC. Аналіз функціонального стану ендотелію за допомогою ЦЕМ CD32+CD40+ показав наявність ендотеліальної дисфункції у групах хворих на IXС та ІХС в Умовах НАЖХП. При порівнянні показників системного запалення низької інтенсивності та маркера ендотеліальної дисфункції у хворих на IXС та IXС у поєднанні з НАЖХП виявлено достовірне підвищення рівня TNFa, реактанта гострої фази та фактора коагуляції - ФГ та експресії гену mRNA IkBa у хворих на коморбідну патологію, що свідчить про підвищення рівню системного запалення низької інтенсивності у хворих на IXС в Умовах НАЖХП порівняно з групою хворих на IXC.
\end{abstract}

Ключові слова: ішемічна хвороба серця, неалкогольна жирова хвороба печінки, хронічне системне запалення, ендотеліальна дисфункція.

Nowadays, coronary heart disease and non-alchoholic fatty liver disease are significant problems in Ukraine and world. Functional liver disorders potentiate the development and progression of CHD. The initiation process of atherosclerosis is a chronic systemic inflammation of low intensity. This view on atherosclerosis development has been forming during the past two decades. The aim of the research was to study the features/characteristics of systemic inflammation of low intensity in patients with coronary heart disease in combination with non-alcoholic fatty liver disease. The research involved 135 people with CHD: stable angina, I-II functional class, 0-I heart failure in combination with non-alcoholic fatty liver disease and 30 healthy individuals. We examined patients in terms of blood levels of cytokines -TNFa and IL-10, the content of the acute phase reactant and the coagulation factor, the marker of endothelial dysfunction is the amount of circulating endothelial microparticles (CEM) $C D 32^{+} C D 40^{+}$and the expression level of IkBa gene NF-kB in mononuclear peripheral blood. We studied the level of expression of the MRNA gene of IkBa in mononuclear cells, which reflects the level of transcriptional activity of NF-KB in patients with stable coronary artery disease and CHD in combination with NAFLD showed a significant increase in the expression of the mRNA gene of IkBa by $88.5 \%$ compared to patients with stable stable coronary heart disease. The analysis of the functional state of the endothelium with help of CEM CD32+

To cite this english version: Yu.I. Manusha, Yu.M. Kazakov, T.A. Trybrat, K.E. Ischeykin. Peculiarities of systemic inflammation of low intensity in patients with stable coronary heart disease concurrent with non-alcoholic fatty liver disease. // The Medical and ecological problems. - 2019. - Vol 23, № 3-4. - P. 3-6. 
ToM 23, N 3-4 2019 p.

CD40+ has shown the presence of endothelial dysfunction in the groups of patients with CHD and CHD in combination with of NAFLD. Comparison of the indicators of systemic inflammation of low intensity and marker of endothelial dysfunction in patients with CHD in combination with NAFLD revealed a significant increase of TNFa, acute phase reactant and coagulation fibrinogen factor and expression of the mRNA IkBa gene in patients with comorbidity, indicating an increase the level of systemic inflammation of low intensity in patients with CHD in combination with NAFLD as compared with the group of patients with CHD.

Key words: coronary heart disease, non-alcoholic fatty liver disease, chronic systemic inflammation, endothelial dysfunction.

\section{Introduction}

This work is a part of planned research project of the Department of Propaedeutics of Internal Medicine with Medical Attendance, General Practice (Family Medicine), UMSA entitled: "Features of the course and prognosis of metabolic syndrome taking into account the genetic, age, gender aspects of patients, the availability of various components in metabolic syndrome and specific accompanying pathology and the ways of correction of detected disorders" (state registration No. 0114U001909).

Coronary heart disease and non-alcoholic fatty liver disease are relevant problems of the present day in Ukraine and in the world.

The initiation process of atherosclerosis is a chronic systemic inflammation of low intensity. This view on the development of atherosclerosis began active development last two decades $[9,10]$. Numerous studies prove the close connection between systemic inflammation of low intensity, oxidative stress and atherosclerotic lesions of the vascular wall [12].

Scientific achievements of recent years recognize endothelial dysfunction as one of the most important links in the pathogenesis of atherosclerosis $[1,2,17]$. Disturbance of the endothelium properties in result of damaging of the cell membrane by free radicals, modified LDL, antigenic complexes, monocytes-macrophages, cytokines, leads to activation of endothelial cells with subsequent apoptosis and formation of a stable imbalance of all endothelialdependent functions [18].

Immunocompetent cells and cytokines play an important role in the formation of atherosclerosis.

The proliferation cytokines Th1 of immune response are IL-1, IL-6, IL-8, TNF- $\alpha$, $\gamma$-interferon (IFNY) have a wide range of effects at different levels of inflammatory process in the body as induces the synthesis of acute phase proteins by hepatocytes, involved in proliferation and differentiation of T- and B-lymphocytes, production of immunoglobulins, natural killers (NK), increase the functional activity of neutrophils, fibroblasts, activate phagocytosis, affect the expression of endothelial cells of adhesion molecules, etc. [3].

A powerful source of inflammatory cytokines is an excess of adipose tissue in the body. Adipocytes accumulated with lipids produce a large number of proinflammatory cytokines which are activators of chronic inflammation. The excess of fatty acids (FA) in the blood is also an important component of low-density heart disease.

The main component of chronic systemic inflammation (CSI) is the nuclear factor of Kappa B (NF-kB) $[4,5,6,7,11]$, whose activation occurs with TNFa, IL-6.

The aim of the research is to study the features of systemic inflammation of low intensity in patients with stable coronary heart disease in combination with non-alcoholic fatty liver disease.

\section{Materials and methods}

In the research were involved 135 people with $\mathrm{CHD}$ : stable angina, I-II functional class, $0-I$ heart failure in combination with non-alcoholic fatty liver disease and 30 healthy individuals.

The diagnosis of CHD was carried out according to the recommendations of the European Society of Cardiology, the Order of the Ministry of Health of Ukraine No. 436 dated July 3, 2006, "On approval of the protocols for the provision of medical care in the specialty" Cardiology", according to the Unified clinical protocol for medical care" Coronary heart disease: stable angina. Primary Aid", according to the Order of the Ministry of Health of Ukraine No. 816 dated 23.11.2011, and the Unified Clinical Protocol for primary, secondary (specialized) and tertiary (highly specialized) medical care" Stable coronary heart disease ", effective from 2015 [15].

Diagnosis of NAFLD was established in accordance with the recommendations of the Order of the Ministry of Health of Ukraine dated November 6, 2014, No. 826 "On Approval and Implementation of Medical-Technological Documents for the Standardization of Medical Assistance in Chronic Non-Infectious Hepatitis", as well as practical recommendations of the American Association for the Study of Liver Diseases, the American College of Gastroenterology and the American gastroenterological association [16,14].

The criteria of exclusion were the following : the cardiovascular system - the presence of hypertension above the second stage, unstable angina or angina III and IV classes, chronic heart failure (CHF) above stage I, acute myocardial infarction, congenital and acquired heart defects, diabetes mellitus type I, chronic and acute viral hepatitis, alcoholic liver disease, autoimmune hepatitis, Wilson-Konovalov's disease, hemochromatosis, rheumatic diseases, anemia, endocrine diseases, chronic liver and kidney disease with a disease deficiency I musculoskeletal inflammatory genesis in the acute stage, cancer.

In order to estimate the level of CSI measured concentration in serum cytokines: TNFa, IL- 6 and IL-10 by (ELISA) which is based on solid-phase "sandwich" variant of enzyme immunoassay using mono- and polyclonal antibodies [13]. We used PCR to determine gene expression inhibitor of kappa $B \alpha(\mathrm{lkB \alpha})$ in real time (Real-time PCR) in peripheral blood mononuclear cells using detective amplifier DT Light ("DNA Technology", Russia). For cDNA, an inverse transcription reaction was performed using a set of reagents (SYNTOL, Russia). The total RNA was taken from a biological sample using a kit of reagents "fish-in-sol» (AmpliSens, Russia). The genome of the "household" GAPDH was used as a reference gene. The $\mathrm{Ct}$ method was used to analyze the data obtained and calculated using the formula $2-\Delta \mathrm{Ct}$ and $2-\Delta \triangle \mathrm{CT}$. In order to establish endothelial dysfunction (ED) using flow cytometry laboratory method to determine the number TSEM in peripheral blood by identifying the expression of antigens CD32 and CD40 circulating endothelial microparticles (CEM) [8]. In the supernatant was determined by CD32+CD40+ - microparticles in flown cytometry «EPIX LX-MCL» (Beckman Coulter, USA) using the «System II TM software». Fluorescence was reached by argon lasers. Identification of endothelial phenotype was performed using 
mouse monoclonal antibody ( $\lg G$ ) to surface antigens that have been labeled with fluorescent dyes. For control, fluorescence dye spotted with mouse lgG was used.

The statistical analysis of the data from the research results was carried out by the KyPlot' licensing program (KyensLab Inc., version 5.0). The hypothesis of normal distribution was checked by the criterion of Shapiro-Wilk.

The verification of the one set samples was carried out by the rank criterion of Crackel-Wallis. The Student's t-test was used for comparative analysis of the examination's results of the patients before and after treatment, the non-parametric pairwise criterion of Wilcoxon was used in the case of uneven distribution.

The data of three independent groups were analyzed with help odd Student's t-test and corrected by Bonferonium with normal distribution and for abnormal distribution the Still-Dwass criterion was used. The correlation between the variables was established by the Pearson's correlation analysis, in the case of non-uniform was used Spearman rank correlations. The results of the statistical analysis are presented in the form $X+\sigma$, where $X$ means value, $\sigma$ means square deviation. The data were evaluated as reliable when the significance level of $p$ was $<0.05$.

\section{The results and discussion}

The goal of research of the activity level of chronic systemic inflammation of low intensity in patients with stable angina of $\mathrm{CHD}$ and $\mathrm{CHD}$ in combination with NAFLD were examined the blood levels of TNF $\alpha$ and IL-10 cytokines in the blood, the content of the acute phase reactant and coagulation factor - fibrinogen, the marker of endothelial dysfunction - the number of circulating endothelial microparticles $\mathrm{CD} 32+\mathrm{CD} 40+$ and the level of expression of the $\mathrm{lkBa}$ gene NF-kB in mononuclear peripheral blood.

The analysis of the level of cytokines revealed in both groups the study of increase in the concentration of proinflammatory cytokines - TNFa (in healthy subjects - 0.5 (percentile interval - 0-6) pg / $\mathrm{ml}$ ), as well as an increase in the mean value of the anti-inflammatory IL-10 CC, which healthy individuals is $5 \mathrm{pg} / \mathrm{ml}$. A significantly higher TNFa level in patients with coronary artery disease in combination with NAFLD ( $p<0.001$ ) was found, compared with a group of patients with coronary artery disease. The probable difference between the groups for the level of IL-10 is not defined $(p>0.05)$ (Table 1).

Table 1.

Levels of blood cytokines in patients with coronary artery disease in association with NAFLD

\begin{tabular}{|c|c|c|}
\hline $\begin{array}{c}\text { Group / } \\
\text { Indicator, } \mathrm{X} \pm \sigma\end{array}$ & $\begin{array}{c}\text { Patients } \\
\text { with CHD, } \\
\mathrm{n}=25\end{array}$ & $\begin{array}{c}\text { Patients with CHD } \\
\text { in combination with } \\
\text { NAFLD, } \mathrm{n}=110\end{array}$ \\
\hline $\mathrm{TNFa}, \mathrm{pg} / \mathrm{ml}$ & $8.48+2.15$ & $10.56 \pm 3.74^{*}$ \\
\hline $\mathrm{IL}-10, \mathrm{pg} / \mathrm{ml}$ & $10.64 \pm 3.54$ & $11.43 \pm 2.12$ \\
\hline
\end{tabular}

Note $^{*}$ - the probable difference as compared with the data of patients with $\mathrm{CHD}(p<0,05)$.

The content of fibrinogen in the blood plasma was elevated in $37 \%$ of patients with stable angina CHD and in $54 \%$ of patients with CHD in association with NAFLD and a probable increase in patients with comorbidity was found in comparison with patients with CHD - 4.65 + 0.91 and $3.79+0.80$ respectively $(p<0.05)$.

Investigation of the level of expression of the mRNA gene of IkBa in mononuclear cells reflects the level of transcriptional activity of NF-kB, and, accordingly, the severity of systemic inflammation of low intensity, in patients with stable coronary artery disease and CHD in combination with NAFLD showed a significant increase $(p<0.001)$ expression of the mKRNA gene of $\mathrm{IkBa}$ by $88.5 \%$ compared to patients with stable stable coronary heart disease (tab.2)

Table 2.

Expression of II Kappa B-alpha mRNA level

\begin{tabular}{|c|c|c|}
\hline $\begin{array}{c}\text { Group /Indicator, } \\
\mathrm{X} \pm \sigma\end{array}$ & $\begin{array}{c}\text { Patients } \\
\text { with CHD, } \\
\mathrm{n}=25\end{array}$ & $\begin{array}{c}\text { Patients with CHD } \\
\text { in combination with } \\
\text { NAFLD, } n=110\end{array}$ \\
\hline $\begin{array}{c}\text { Eкспресія mRNA } \\
\text { IkBa, } 2^{-\mathrm{-OCt}}\end{array}$ & $0.0247 \pm 0.0165$ & $0.215^{*} \pm 0.048$ \\
\hline
\end{tabular}

Note: * the probable difference as compared with data in patients with $\mathrm{CHD}(p<0.001)$.

The patients who have stable $\mathrm{CHD}$ and $\mathrm{CHD}$ in combination with NAFLD revealed increasing number of CEM CD32 + CD40 + in the blood stream $(p<0.05)$ in comparing with group of almost healthy patients. This indicator had no significant changes in comparison with patients with CHD and patients with comorbid pathology (Table 3 ).

Table 3

The content of circulating endothelial microparticles CD $32^{+}$ $C D 40^{+}$in patients with stable $\mathrm{CHD}$ and $\mathrm{CHD}$ in association with NAFLD

\begin{tabular}{|c|c|c|c|}
\hline $\begin{array}{c}\text { Group / } \\
\text { Indicator, } X \pm \sigma\end{array}$ & $\begin{array}{c}\text { Healthy } \\
\text { patients, } \\
\mathrm{n}=30\end{array}$ & $\begin{array}{c}\text { Patients } \\
\text { with CHD, } \\
\mathrm{n}=25\end{array}$ & $\begin{array}{c}\text { Patients with } \\
\text { CHD in com- } \\
\text { bination with } \\
\text { NAFLD, } \\
\mathrm{n}=110\end{array}$ \\
\hline $\begin{array}{c}\mathrm{CD} 32^{+} \mathrm{CD} 40^{+}, \\
\times 10^{7} / /\end{array}$ & $1.43 \pm 0.19$ & $2.93 \pm 0.69^{*}$ & $2,95 \pm 1.94^{*}$ \\
\hline
\end{tabular}

Note: * - the probable difference as compared with the data of apparently healthy persons $(p<0,05)$.

Consequently, the analysis of functional state of the endothelium with help of $\mathrm{CDM}^{+} \mathrm{CD}^{+} 0^{+}$has shown the presence of endothelial dysfunction in the groups of patients with $\mathrm{CHD}$ and $\mathrm{CHD}$ in combination with NAFLD.

\section{Conclusions}

Thus, comparison of indicators in systemic inflammation of low intensity and the marker of endothelial dysfunction in patients with $\mathrm{CHD}$ and $\mathrm{CHD}$ in combination with NAFLD revealed a significant increase in the level of TNF $\alpha$, acute phase reactant and coagulation factor-FG and expression of the mRNA gene of IkBa in patients with comorbid pathology was found testify to an increase in the level of systemic inflammation of low intensity in patients with coronary heart disease under conditions of NAFLD as compared to the group of patients with coronary heart disease.

\section{References}

1. Amosova KM, Stremenyuk OT, Andreev EV et al. The role of endothelial dysfunction and systemic immune inflammation in the occurrence of myocardial ischemia with physical activity in patients with hemodynamically insignificant atherosclerosis of the coronary arteries of the heart. Ukrainian Cardiology Journal. 2011;4:14-19.

2. Berezin $A E$, Kruzlyak P. Circulating endothelial apoptotic microparticles as a new marker of cardiovascular risk. Ukrainian Medical Journal. 2014;5(103):83-87.

3. Brunetti ND, Correale M, Pellegrino PL et al. Early inflammatory cytokine response: A direct comparison between spontaneous coronary plaque destabilization vs angioplasty induced. Atherosclerosis. 2014;236(2):456-460.

4. Chekalina N, Burmak Yu, Petrov Ye, Borisova Z et al Quercetin reduces the transcriptional activity of NF-kB in stable coronary artery disease. Indian Heart Journal. 2018. https://doi.org/10.1016/j.ihj.2018.04.006

5. Chekalina NI, Kazakov YuM, Mamontova TV, Vesnina LE et al. Resveratrol more effectively than quercetin reduces 
ToM 23, N 3-4 2019 p.

endothelium degeneration and level ofnecrosis factor $\alpha$ in patients with coronary artery disease. Wiadomosci Lekarskie. 2016;69(3):479-483.

6. Chekalina NI, Shut SV, Trybrat TA, Burmak YuH et al. Effect of quercetin on parameters of central hemodynamics and myocardial ischemia in patients with stable coronary heart disease. Wiadomosci Lekarskie. 2017; 70(4):707-711

7. Kaidashev IP. Activation of the nuclear factor $k B$ as the molecular basis of the pathogenesis of the metabolic syndrome. Pathol Physiol and Experim Ther. 2013;(3):65-72

8. Kutsenko NL, Savchenko LG, Kaydasheva EI, Kutsenko $\mathrm{LA}$ et al. Determination of circulating CD32+ CD40+ microparticles - modification of degradation assessment of endothelial cells. Clinical Laboratory Diagnostics. 2011;7:20-23

9. Loboda OM, Krasyuk IV, Alekseeva VV et al. Interconnection of processes of lipid peroxidation and chronic inflammation with atherosclerotic vascular changes and endothelial dysfunction indices in patients with CKD of II-IV stages. Ukrainian Journal of Nephrology and Dialysis. 2015;1:13-20.

10. Lutai MI, Golikova IP, Slobodskaya VA. The role of dysfunction of endothelium, inflammation and dyslipidemia in atherogenesis. Ukrainian Cardiology Journal. 2007;5:37-47
11. Martin RDe, Hoeth $M$, Hofer-Warbinek R. The transcription factor NFkappa B and the regulation of vascular cell function. Arterioscler Thromb Vasc Biol. 2000;20(11):83-88

12. Ragino YI, Cherniavsky AM, Polonskaya Ya., Volkov AM et al. Investigations of the vascular wall and blood. Bulletin of Experimental Biology and Medicine. 2012;153 (3):308

13. Sennikov SV, Silkov AN. Methods of cytokine detection Cytokines and inflammation..2005;1(4):22-27.

14. Tangney C, Rasmussen HE. Polyphenols, inflammation, and cardiovascular disease. Curr. Atheroscler. Rep. 2013;15( 5):324.

15. Unified clinical protocol "Stable coronary heart disease". Order of the Ministry of Health of Ukraine No. 152 dated 02.03.2016.

16. Unified clinical protocol "Non-alcoholic steatohepatitis". Order of the Ministry of Health of Ukraine No. 826 dated November 6, 2014.

17. Zaremba $\mathrm{YeH}$, Smalukh OV. Inflammation markers and endothelial function in patients with coronary heart disease. Bukovinsky Medical Bulletin. 2014;18.4(72):195-

18. Zolotareva NA, Romanchenko MI. Endothelial dysfunction: diagnostic significance, methods of determination. Odessa Medical Journal. 2013;2:77-84.

Матеріал надійшов до редакції 28.03.2019 р. 